TITLE:

\title{
Phase Shift Analysis for p-4He Elastic Scattering at 45, 52, 60 and $65 \mathrm{MeV}$ (Abstract_要旨)
}

AUTHOR(S):

Saito, Takane

CITATION:

Saito, Takane. Phase Shift Analysis for p-4He Elastic Scattering at 45, 52, 60 and $65 \mathrm{MeV}$. 京 都大学, 1980, 理学博士

ISSUE DATE:

1980-01-23

URL:

http://hdl.handle.net/2433/222471

RIGHT: 


\section{【103】}

氏 名齊藤高嵩惄

学位の種類 “理 学博 士

学位記番号 論理 博 第 673 号

学位授与の日付 昭 和 55 年 1 月 23 日

学位授与の要件，学位規則第 5 条第 2 項該 当

学位論文題目 Phase Shift Analysis for $\mathrm{p}-{ }^{4} \mathrm{He}$ Elastic Scattering at $45,52,60$ and $65 \mathrm{MeV}$

（45，52，60 及び $65 \mathrm{MeV}$ そおける陽子一ーリウム 4 弾性散乱の 位相のずれの解析)

論文調査委員教授小林晨作 教授三宅弘三教授玉垣良三

\section{論 文内容 の要 旨}

陽子のへリウム 4 原子核による弾性散乱は, ヘリウム 4 が陽子 2 個中性子 2 個で構成された最も簡単な 本格的原子核であるため原子核反応，及び原子核構造の研究において基礎となる重要な反応である。また 一方，へリウム 4 原子核の励起状態が基底状態上り $20 \mathrm{MeV}$ 以上はなれて和り，かつ陽子に対して比較的 大きなスピン偏極度分解能を広いェネルギー範囲にかたって有するため, スピン偏極度の基準としても重 要な反応である。このため非弾性散乱の抽こる $23 \mathrm{MeV}$ 以下のエネルギー領域では各国の研究者によっ て非常に多くの研究がなされ，陽子一ーリウム 4 の弾性散乱の微分断面積及び陽子偏極度の大量の実験デ 一タをもとに系統的な解析がなされ，反応関与する部分波の略完全に信頼しらる位相差が得られ，これ らのデータをるとに“陽子一ーリウム $4 ”$ の 5 体系の構造或いは反応機構の理論的研究も進められている。

しかし非弾性散乱の起るエネルギー領域では実験データが極めて少く, 系統的な研究としては, 最近委 でバークレーの実験グループによる $20 \mathrm{MeV}$ より $40 \mathrm{MeV}$ までの微分断面積と陽子偏極度のデータととれ らにもとづいた同グループによる位相差解析の仕事しか存在していなかった。このような研究の段階に於 いて申請者は更に高いエネルギー領域まで5 体系に関する実験的理解を深めるために西村等と共に阪大核 物理研究センターの AVF サイクロトロンを用い $45,52 ， 60 ， 65 \mathrm{MeV}$ の各エネルギー点に拮いて陽子一 ヘリウム散乱の微分断面積と偏極度の精密な測定を行った。これらの微分断面積と偏極度のデータを用い て申請者が位相差解析を行った報告が本論文である。陽子一ーリウム 4 散乱に対しては非弾性散乱の抗こ らない低いエネルギー領域ではこの解析は比較的容易であるが本論文で対象としているエネルギー領域で は非弾性散乱の寄与は非常に大きく，従って関与する部分波は $\mathrm{H}$ 波までの 6 個，更に各部分波は吸収のた め実部と虚部にわかれ全部で 22 個のパラメタを有する部分波解析を，エネルギーの高さを考光て相対論 的に行う必要がある。日本には今までこのような解析プログラムは存在していなかった。著者はFoote 他 によって提案されている方法によってクーロン散乱振巾に相対論的補正を行い高工研で小柳氏によって開 発された非線型関数に対する最小二乗評価の方法をサブルーチンとするプログラムを製作した。解析は 
より低エネルギーの值を中心にいくつかの出発值を用い特に解の一意性に注意して行われた。この結果, バークレーの解は一意的なものではなく, バークレーの用いたデータのみでは解が 4 つ存在すること, そ の解を限定するために前方のクーロン相互作用と核力の干渉が現れる領域を含む角度範囲での偏極度のデ 一タが有効である事を指摘し，前方散乱のデータを補充し，これにより解を 2 つに限定することに成功し た。また解を更に つつにばるため，スピン回転度の後方角での測定が有効であることを解析にもとずき 指摘している。更に得られた二つの解の散乱振巾を再構成して調べた結果，そのうちの一つの解は60〜 65 $\mathrm{MeV}$ のエネルギーの間の一点で偏極度が 1 となる点を有することを見出した。

\section{論文審査の結果の要旨}

陽子一へリウム 4 の弾性散乱は原子核物理学にとって基本的な反応である。それは一つにはへリウム 4 が本格的な結合エネルギーをもつ原子核の中で最も簡単なるのであることである。更にその第一励起状態 が $20 \mathrm{MeV}$ 以上の励起エネルギーをもち, 弾性散乱が主要な反応であり，そのため反応機構の研究にとっ て都合がよいことと，スピン偏極分解能が広いエネルギー範围にわたって大きいという特殊事情がある。 この研究は従来系統的データの少なかったエネルギー領域にこの反応の研究を拡大し, 位相差に関する知 見を増大させた。これは陽子一へリウム 4 系といら基本的な核に対する貴重な情報である。解析の方法は 基本的には従来の信頼できる手段に基ついているが，方法の細部にわたって独創性が認められる。又エネ ルギー領域拡大に伴ってなされなければならない補正, 例えば相対論的補正を適確に行っている。従って 得られた知見は信頼出来るものと考学られる。解析の結果, 従来のバークレーの解析の欠陥を明らかにし， その修正を行った。又, 解のユニークさについての追求を行い, どらいう実験を行えばよいかを提案し, その一部は既に行われ解の一意性について大きく前進した。又, 位相差解析にとどまらず散乱振巾を再構 成し，夫々の解がどのような特性をもっているかを調べ，龺の特長を明らかにした。これも従来の研究で はなされていない点で, 申請者の独創性を示す点とい方る。本研究の結果は陽子ェネルギー $40 \mathrm{MeV}$ から $70 \mathrm{MeV}$ の領域での核反応機構の研究にとって特にそのスピン依存性の研究にとって, 今後基本となるも ので，その意義は大きいとい方る。本論文ならびに本研究に関連した実験に関する参考論文よりみて，申 請者の核物理学の精密実験に対する力倆は，極めて高いと判断される。

よって, 本論文は理学博士の学位論文として価値あるものと認める。 